(Uniwersytet Jana Kochanowskiego, Kielce, e-mail: Kowalczyk@ujk.edu.pl)

ORCID: 0000-0001-5571-5175

\title{
O NIEUJEDNOLICONEJ SEMANTYCE TERMINÓW CZYNNOŚĆ SEKSUALNA, INNA CZYNNOŚĆ SEKSUALNA I OBCOWANIE PECIOWE W DYSKURSIE PRAWNYM
}

\begin{abstract}
WSTĘP
Dyskurs prawny nasycony jest terminologia porządkująca świat formalny (obejmujaccy przypisane statusy normatywne) i rzeczywisty (dotyczący stanów faktycznych). W zależności od natury przedmiotu opisu ustawodawca stosuje uogólnione bąź precyzyjne formy charakteryzowania fragmentów rzeczywistości, które podlegaja regulacjom prawnym. Szczególne trudności pojawiają się wówczas, gdy systematyzacją obejmowane sa obszary życia $z$ założenia prywatne, intymne, wstydliwe, obarczone kulturowo-społecznym tabu, takie jak seksualna sfera bytowania człowieka. Trudności te dotycza nie tylko tego, co można lub należy właczyć w obręb uregulowań ustawowych, ale wiąża się także z problemem ustalenia zakresu, jednoznacznie wyznaczającego granice między tym, co dozwolone, a tym, co zabronione.

Jedna $z$ takich dyskusyjnych kwestii jest seksualność rozumiana po pierwsze jako domena osobista, po wtóre - jako domena prawna, majaca dwa poziomy. Pierwszy poziom domeny prawnej odnosi się do seksualności będącej uniwersalnym prawem człowieka, otoczonym ochrona ustawodawcy, drugi wiąże się z czynami godzacymi w te prawa, tj. wykroczeniami i przestepstwami na tle seksualnym.

Przedmiotem oglądu uczyniono stosowane w ustawodawstwie terminy nazywajace akty seksualne, tj. czynność seksualna, inna czynność seksualna oraz obcowanie płciowe. Wymienione jednostki nazewnicze rozpatrywano w kontekście założeń normatywnych, jurysdykcyjnych i ustaleń doktrynalnych.

Materiał poddany analizie zaczerpnięto przede wszystkim z Kodeksu karnego [KK], orzeczeń sądowych oraz glos do orzeczeń sądowych. Źródłami uzupełniajacymi były Kodeks wykroczeń [KW] i Ustawa o ochronie zwierząt [UoOZ]. W toku badania korzystano również z ustaleń zawartych w międzynarodowych dokumentach poświęconych seksualności: Deklaracji praw seksualnych przyjętej przez Światową Organizacja Zdro-
\end{abstract}


wia [DPS] oraz Deklaracji praw seksualnych człowieka wydanej przez Światowa Organizację Zdrowia Seksualnego [DPSC].

Celem opracowania jest semantyczne uspójnienie zakresów omawianych pojęć, funkcjonujących jako terminy prawne, lecz niemających wykładni ustawowej, doprecyzowanie ich znaczeń, a także ustalenie, czy istnieja ontologiczne cechy, mogące jednoznacznie zróżnicować wszystkie koncepty.

Za metodologiczna podstawę prowadzonej analizy uznano kryterium językowo-systemowe [Paprzycki 2008, 84], które umożliwiło uchwycenie szczególnej, tj. zgodnej $z$ pragmatyka dyskursu prawnego, semantyki wyabstrahowanych $z$ ustawy terminów nazywajacych akty seksualne. Należy bowiem zaznaczyć, że forma werbalna tych jednostek nie była jedynie elementem konwencji tekstu, ale sygnałem do odróżniania poszczególnych denotacji w świecie rzeczywistym.

\section{SEKSUALNOŚĆ JAKO PRZEDMIOT DYSKURSU OFICJALNEGO}

Seksualność znajduje się w kręgu zainteresowania wielu podmiotów: władz publicznych, instytucji naukowych i społecznych, osób prywatnych itd. Roztaczana wizja prawna w krajach demokratycznych kształtuje obraz seksualności jako podstawowej wartości osobistej, wymagajacej poszanowania i ochrony.

W ramach polskiego ustroju społeczno-politycznego najważniejszymi dokumentami regulującymi zagadnienia seksualności sa Kodeks karny oraz Deklaracja praw seksualnych wydana przez Światowa Organizację Zdrowia. Za akt pomocniczy wobec dwóch powyższych uznaje się Deklaracje praw seksualnych człowieka [por. m.in. Glińska 2016] wydana przez Swiatową Organizację Zdrowia Seksualnego.

W założeniach przedstawionych w dokumencie Światowej Organizacji Zdrowia seksualność opisywana jest jako „prawa seksualne”, wymagające pieczy ustawowej każdego państwa, gdyż należą do kategorii uniwersalnych i niezbywalnych wolności człowieka. $Z$ tego powodu „wszystkie społeczeństwa muszą uznawać, promować, szanować (...) prawa seksualne i bronić ich wszystkimi środkami" [DPS].

Deklaracja praw seksualnych człowieka oprócz afirmacji twierdzeń Światowej Organizacji Zdrowia rozszerzyła postanowienie o czynnik określajacy obowiązki państwa wobec wszystkich członków wspólnoty co do zagwarantowania im praw seksualnych w konstytucjach (ustawach zasadniczych), ustawach i innych aktach normatywnych. Zasadniczym punktem stało się eksplicytne wskazanie, że w państwie demokratycznym obligatoryjnym elementem systemu jest zagwarantowanie osobom poszkodowanym przestępstwem na tle seksualnym karno-cywilnej ochrony prawnej, por.: 
Każdy człowiek ma prawo dostępu do wymiaru sprawiedliwości, środków naprawczych i odszkodowawczych w zakresie naruszenia lub pogwałcenia praw seksualnych. Niniejsze prawo wymaga stosowania skutecznych, właściwych, dostępnych oraz stosownych środków edukacyjnych, legislacyjnych, sadowych oraz wszelkich innych środków. Środki naprawcze obejmuja środki odszkodowawcze oraz zadośćuczynienia, w tym przywrócenie stanu poprzedniego, odszkodowanie (rekompensatę), rehabilitację, zadośćuczynienie oraz gwarancję, że dane działania nie będą miały miejsca ponownie [p. 16 DPSC].

Analogiczne sady formułowane sa w polskim Kodeksie karnym, z tą jednak różnica, że w polskiej ustawie termin prawa seksualne jest reprezentowany przez frazem wolność seksualna, por.:

- Kto (...) narusza wolność seksualna osoby (...) podlega karze [118a § $2 \mathrm{KK}$;

- przestępstwo przeciwko (...) wolności seksualnej w związku z zaburzeniem preferencji seksualnych [art. 93g. § $3 \mathrm{KK}$ ].

Warto zauważyć, że ukonkretniony charakter polskiej ustawy zbudował bliższy rodzimym warunkom kulturowo-cywilizacyjnym horyzont wykorzystywania pojęcia wolność seksualna poprzez rozszerzenie go o element obyczajność. Kontekst pragmatyczny pozwolił ustalić, że obyczajności w tym wypadku nadano znaczenie: 'cenzuralny, moralnie właściwy', por.:

- Przestępstwa przeciwko wolności seksualnej i obyczajności [XXV KK].

Posługując się wyrażeniem wolność seksualna $i$ obyczajność, polski ustawodawca dał ponadto wyraz społecznego odium wobec osób naruszających prawo na szkodę dzieci, gdyż w sześciu na osiem możliwych przykładów użycia tej jednostki nazewniczej odwołał się do przestępstw przeciwko osobom małoletnim, por.:

- (...) w razie skazania za przestępstwo przeciwko wolności seksualnej lub obyczajności na szkodę małoletniego [art. $41 \S 1 \mathrm{a} \mathrm{KK}]$.

Cząstka obyczajność zdeterminowała ogólną semantykę wyrażenia poprzez wskazanie, że granica szkodliwości rozpoczyna się już od czynów moralnie nagannych, a nie dopiero od bezpośrednich działań na tle seksualnym. To oznacza, że za przestępstwo uznana zostanie również działalność mogacca prowadzić do demoralizacji nieletniego, np. wskutek udostępniania mu treści pornograficznych, por.:

- Kto małoletniemu poniżej lat 15 prezentuje treści pornograficzne (...) albo rozpowszechnia treści pornograficzne w sposób umożliwiający takiemu małoletniemu zapoznanie się $z$ nimi, podlega karze [art. 200 § $3 \mathrm{KK}$ ].

Majac na uwadze ochronę tak rozumianych praw seksualnych, prawodawca wprowadził do Kodeksu karnego terminy: czynność seksualna, inna czynność seksualna oraz obcowanie ptciowe. Na podstawie tego 
trzystopniowego podziału każdorazowo dokonuje się interpretacji, który zakres znamion wyczerpał rozpatrywany akt seksualny. Ze względu na to, że żadna $z$ powyższych kategorii nie ma definicji ustawowej, na gruncie orzeczeń sądowych i ustaleń doktrynalnych podejmowane są próby ich wyjaśnienia. $\mathrm{W}$ opiniach jurysdykcyjnych i naukowych nie wypracowano jednak do tej pory jednolitego stanowiska, dlatego dalsza część niniejszego opracowania zostanie poświęcona próbie doprecyzowania znaczeń omawianych konceptów poprzez ustalenie ich esencjonalnych cech, jednoznacznie różnicujących wszystkie pojęcia.

\section{POJĘCIE <CZYNNOŚĆ SEKSUALNA>}

Przeprowadzony na potrzeby niniejszego opracowania ogląd pragmatyczno-semantyczny wykazał, że termin czynność seksualna w odniesieniu do wyrażeń obcowanie płciowe i inna czynność seksualna charakteryzuje się najszerszym zakresem znaczeniowym i funkcjonalnym, a tym samym jest kategoria nadrzędną. Fakt, że pojęcie <czynność seksualna> stanowiło najbardziej uogólniona formę nazywania aktywności seksualnej, nie był jednak okolicznością ułatwiającą zdefiniowanie tego pojęcia, gdyż ani w opisach doktrynalnych, ani orzeczniczych nie podano definicji czynności seksualnej właśnie ze względu na jej abstrakcyjność. Opisy prawne i prawnicze skupiały się bowiem albo na podkreśleniu, że czynność seksualna to „znamię ogólne, zawierające w sobie zarówno zakres desygnatów pojęcia obcowanie płciowe, jak i inna czynność seksualna" [Wrześniewski 2012, 38], albo na próbach zdefiniowania konceptów pokrewnych, ale uściślonych chociażby przez katalog egzemplifikacji w świecie rzeczywistym, takich jak <zgwałcenie>.

Chcąc więc sprecyzować, czym jest czynność seksualna, w toku prowadzonej analizy skoncentrowano się na ustaleniu właściwej pragmatyki kontekstów użycia terminu zarówno w opisach normatywnych (ustawowych), jak i orzeczniczych. Na podstawie pragmatycznego kontekstu stosowania omawianego terminu ustalono, że czynność seksualna stanowi uogólniona nazwę wszystkich możliwych aktywności związanych z zaangażowaniem cielesnym na tle seksualnym.

Czynność seksualna była przede wszystkim utożsamiana $z$ intuicyjnym rozumieniem pojęcia <doświadczenia seksualne>, które obejmowało swym zasięgiem wszelkie działania związane $z$ angażowaniem części ciała kulturowo uznanych za erotyczne por.:

- [czynność seksualna to kontakty seksualne] wielokrotnie inicjował z jego udziałem kontakty seksualne (...), czym doprowadził go do poddania się różnego rodzaju czynnościom seksualnym [I C 377/14];

- [czynność seksualna to seks] Fakt, że pokrzywdzona inicjowała czynność seksualną, nie świadczy jeszcze, że tego seksu chciała [II AKa 294/16]; 
- [czynność seksualna to współżycie seksualne] (...) wiek świadomej zgody na współżycie seksualne czy też dokonywanie $\mathrm{z}$ małoletnim innych czynności seksualnych [IV Ka 360/14];

- [czynność seksualna to dotyk] Czynnością seksualną jest więc dotykanie narządów płciowych lub odbytu (...) [II AKa 142/11].

Powyższe ustalenia utworzyły osnowę dla kolejnych etapów przybliżania ontologii pojęcia <czynność seksualna>, które w kontekście prawnym znalazło się pod wpływem dwóch głównych determinantów esencjonalnych: przedmiotowego i podmiotowego.

Kryterium przedmiotowe okazało się funkcjonalne na dwóch poziomach. Pierwszy poziom dotyczył ustalenia, jakie formy działań można uznać za czynność seksualna, drugi - umożliwił kategoryzowanie czynności seksualnych pod względem społeczno-prawnym, tj. jako przestępstwo lub dobro chronione prawem.

Biorac pod uwage pierwszy poziom przedmiotowy, brak definicji czynności seksualnej spowodował, że w tekstach poświęconych tej tematyce albo pomijano tę najogólniejsza formę nazewniczą, albo skupiano się na zbudowaniu katalogu działań, które można odnieść do tego pojęcia poprzez wskazywanie cech jednostkowych, por.:

- czynność seksualna ze swej istoty może mieć charakter penetracyjny lub niepenetracyjny [Wrześniewski 2012, 39],

albo zestawiano omawiany koncept ogólny z konkretnym faktem odnoszacym się do formy aktu seksualnego, por.:

- Czynność seksualna, której dopuściła się Irena W. względem Wiktora G., polegała na odbyciu oralnego stosunku płciowego [Wróbel, Bielski 2011, 152].

Drugi poziom ogladu przedmiotowego ujawnił bilateralny charakter terminu czynność seksualna, który w dyskursie prawnym był traktowany jako przestepstwo lub jako dobro chronione prawem, por.:

- [czynność seksualna jako wartość prywatna] Kto utrwala wizerunek nagiej osoby lub osoby w trakcie czynności seksualnej, używając w tym celu wobec niej przemocy, groźby bezprawnej lub podstępu, albo wizerunek nagiej osoby lub osoby w trakcie czynności seksualnej bez jej zgody rozpowszechnia [art. 191a § $1 \mathrm{KK}$ ];

- [czynność seksualna jako przestępstwo] (...) naruszenie (...) dóbr osobistych, tj. integralności seksualnej, zdrowia oraz godności poprzez doprowadzenie (...) do poddania się czynnościom seksualnym [I C 377/14].

Powyższe przykłady stanowia reprezentatywne odniesienie do sposobów postrzegania czynności seksualnej na gruncie polskiego prawa. Po pierwsze, czynność seksualna traktuje się jako dobro, a dobrem tym jest prawo do prywatności seksualnej, uwzględniające intymność sfery erotycznej każdego człowieka [p. 3 DPS] i ochronę informacji osobistych 
w tym zakresie [p. 6 DPSC]. Po drugie, czynność seksualna może być odnoszona do kategorii przestępstwa, godzącego w wolność seksualna poprzez stosowanie jakichkolwiek form przymusu czy nadużyć [p. 1 DPS].

Kryterium podmiotowe umożliwiło $z$ kolei ustalenie, w jakim stopniu czynnik osobowy wpływa na jakościowe cechy konceptu <czynność seksualna>. Uwzględniając podział na dobro chronione prawem vs przestępstwo, zauważono, że zarówno w relacjach dozwolonych, jak i w relacjach zakazanych funkcjonuja jednostronne, dwu- lub wielostronne akty, które należy kategoryzować jako czynności seksualne. Zatem do klasy pojęcia zostały włączane nie tylko akty wymagające zaangażowania / / kontaktu fizycznego dwóch lub więcej osób, ale również te będące udziałem jednej osoby (np. masturbowanie się). To oznacza, że po pierwsze czynność seksualna nie musi oznaczać relacji co najmniej dwustronnej, a po drugie do pola semantycznego inkorporowane sa w takim samym stopniu czyny seksualne dozwolone (dobra chronione prawem, np. dobrowolne stosunki seksualne osób pełnoletnich), jak i czyny seksualne niedozwolone (przestępstwa, np. stosunki seksualne osób pełnoletnich $z$ osobami poniżej 15. roku życia).

Istotnym elementem esencjonalnym okazał się również fakt, że relacje co najmniej dwustronne nie zawsze zachowuja układ człowiek człowiek. W kategorii czynności seksualnych kwalifikowanych jako przestępstwa ustawodawca przewidział relację człowiek - zwierzę [art. 6 $\S 2$ pkt $16 \mathrm{UoOZ}$ ]. Zatem zakres pojęcia <czynność seksualna> obejmuje również kontakty intymne ze zwierzętami.

Warto zwrócić również uwagę na czynniki przyczynowe i celowościowe, mogace stanowić kryterium oceny w trakcie ustalania, czy konkretne zachowanie było / nie było czynnością seksualna. W praktyce orzeczniczej i doktrynalnej element kauzalny nie ma znaczenia jakościowego, gdyż zaburzenia preferencji seksualnych (np. pedofilia), zbyt wczesna seksualizacja lub błąd co do wieku partnera nie wpływaja na fakt zaistnienia czynności seksualnej. Kwestą sporną pozostaje cel działania, por.:

- [cel seksualny] Warunkiem (...) niezbędnym (...) jest również i to, by zachowanie (...) miało „charakter seksualny”, to jest wiazało się z jakąś formą zaspokojenia lub pobudzenia popędu płciowego" [WA 25/01];

- [cel nieseksualny] Obok tego najczęstszego w praktyce motywu wystapić moga tu bowiem motywy inne, zgoła nieseksualne, jak np. chęć zemsty, poniżenia ofiary, nakłonienie jej do zawarcia małżeństwa, czy wręcz chęć zysku itp. (...) Nie powinniśmy bowiem (nawet gdyby finalnie dawało to w konkretnej sprawie identyczny rezultat) mylić znamion przedmiotu ochrony ze znamionami strony przedmiotowej czy podmiotowej przestępstwa [Filar 2002].

W pierwszym typie interpretacji za immanentny składnik czynności seksualnej uznawana jest motywacja związana $z$ rządza płciowa, w drugim - zdecydowanie neguje się takie stanowisko, wskazując, że determinantem ontologicznym nie jest cel, lecz dobro chronione prawem, tj. 
wolność seksualna rozumiana jako swoboda w nawiązywaniu, utrzymywaniu (kontynuowaniu) oraz zakańczaniu szeroko rozumianych czynności seksualnych [Budyn-Kulik 2008, 172].

Za słuszne należy uznać, że to nie od celu zależy seksualność czynności, ale od wyczerpania znamion kontaktów intymnych (np. zgwałcenie każdorazowo będzie niedozwoloną czynnościa seksualną, nawet jeżeli sprawca działał w celu poniżenia ofiary, a nie w celu zaspokojenia popędu płciowego), por.:

- Dla przyjęcia, że sprawca swoim czynem wyczerpał znamiona tego przestępstwa, jest bowiem istotne nie to, w jakim sprawca działal celu, lecz to, czy swoim zachowaniem - odpowiadającym ustawowemu opisowi - dopuścil się zamachu na wolność seksualną ofiary [II KKN 349/98];

- Bez znaczenia dla uznania zachowania za czynność seksualną będzie to, czy sprawca takie zachowanie podejmujący subiektywnie zmierza do zaspokojenia swojego popędu płciowego, a także to, czy tym zachowaniem wywołał $\mathrm{u}$ ofiary stan podniecenia seksualnego. (...). Istota czynności o charakterze seksualnym jest uznanie danego rodzaju zachowania za formę kontaktu seksualnego w świetle kulturowych wzorców postępowania w sferze życia seksualnego [Bielski 2008, 214-215].

Na podstawie powyższych refleksji przyjęto, że czynność seksualna to każda aktywność wymagająca fizycznego zaangażowania organów płciowych lub ich surogatów co najmniej jednej osoby / istoty i mająca przynajmniej dla jednego uczestnika tej aktywności charakter seksualny ${ }^{1}$ albo wywołująca taki skutek (np. w formie naruszenia czyjejś wolności seksualnej). Zgodnie $z$ polskim ustawodawstwem czynność seksualna może stanowić dobro chronione, będące prawem do swobody w kontaktach erotycznych i prywatności ich realizowania. Może być również czynem niedozwolonym. Za czyn niedozwolony należy ją uznać, gdy narusza czyjąkolwiek wolność seksualną (np. poprzez przymus, groźbę, podstęp) lub $z$ natury prawa jest niedopuszczalna (np. czyny pedofilskie, zoofilia).

\section{POJECCIE <OBCOWANIE PLCIOWE>}

W odróżnieniu od <czynności seksualnej> pojęcie <obcowanie płciowe > w tekstach ustawodawczych wiazano wyłacznie $z$ jedna kategoria, tj. forma wykorzystywania seksualnego. Ustawodawca implicytnie wprowadził pięć typów przestępstw związanych $z$ obcowaniem płciowym.

Pierwsza grupę przestępstw prawodawca skonceptualizował poprzez konglomerat: przemoc, groźba i podstęp, ustanawiając tym samym, że

1 Charakteru seksualnego nie można przypisać działaniom obiektywnie akceptowanym i $z$ natury nieseksualnym, takim jak przeprowadzenie badania stref intymnych czy sprawowanie opieki higienicznej nad dzieckiem lub pacjentem. 
czynem niedozwolonym jest ograniczanie swobody w podejmowaniu decyzji co do kontaktów seksualnych, por.:

- Kto przemoca, groźbą bezprawną lub podstępem doprowadza inną osobę do obcowania płciowego, podlega karze (...) [art. $197 \S 1 \mathrm{KK}$;

- Kto (...) przemoca, groźbą bezprawną lub podstępem doprowadza (...) osoby do obcowania płciowego (...) podlega karze (...) [art. $124 \S 1 \mathrm{KK}]$.

Druga grupę przestępstw stanowiły czyny w postaci kontaktów seksualnych $z$ osobami małoletnimi. Ustawodawca założył bowiem, że ta grupa społeczna wymaga szczególnej atencji, a

przedmiotem ochrony jest tu wolność seksualna małoletniego, która rozumiana jest jako wolność od ingerowania w sferę życia seksualnego, która małoletni nie jest w stanie prawidłowo dysponować [Grześkowiak 2012, 347],

por.:

- Karze (...) podlega, kto obcuje płciowo $\mathbf{z}$ małoletnim (...), nadużywając zaufania lub udzielając $\mathrm{w}$ zamian korzyści majątkowej lub osobistej albo jej obietnicy [art. 191 § $3 \mathrm{KK}$;

- Kto obcuje płciowo $\mathbf{z}$ małoletnim poniżej lat 15 (...), podlega karze (...) [art. 200 $\S 1 \mathrm{KK}]$.

Do tej klasy przestępstw zaliczono również akty pedofilskie, ale należy zauważyć, że nie każde obcowanie płciowe $z$ osoba poniżej 15. roku życia uznaje się za czyn pedofilski, nie sposób bowiem każdorazowo uznać za pedofilię kontaktów seksualnych np. pomiędzy osobą w wieku 17 lat i osoba w wieku lat 14 .

Kolejna kategoria niedozwolonych aktów seksualnych w tym obszarze to kazirodztwo. W tekście ustawy obcowanie płciowe między osobami związanymi stosunkiem bliskiego pokrewieństwa (również stosunkiem adopcji, który jest równoznaczny z pokrewieństwem) zostało potraktowane jako przestępstwo, por.:

- Kto dopuszcza się obcowania płciowego w stosunku do wstępnego, zstępnego, przysposobionego, przysposabiającego, brata lub siostry, podlega karze (...) [art. $201 \mathrm{KK}$ ].

Czwarta klasa czynów niedozwolonych obejmowała obcowanie płciowe $z$ osobami, które ze względu na trwałą niemoc intelektualną lub trwałe albo okresowe zaburzenia świadomości nie sa zdolne do samodzielnego stanowienia o sobie, por.:

- Kto, wykorzystując bezradność innej osoby lub wynikający z upośledzenia umysłowego lub choroby psychicznej brak zdolności tej osoby do rozpoznania znaczenia czynu lub pokierowania swoim postępowaniem, doprowadza ja do obcowania płciowego (...), podlega karze (...) [art. $198 \mathrm{KK}$ ]. 
Ostatni rodzaj przestępstw na tle seksualnym odnosił się do nierówności społecznych i osobistych. Obcowanie płciowe, będące wynikiem poddania się presji wewnętrznej (np. konieczność zaspokojenia podstawowych potrzeb bytowych) lub zewnętrznej (np. mobbing), zostało przez ustawodawcę uznane za niedozwolone i objęte sankcjonowaniem, por.:

- Kto, przez nadużycie stosunku zależności lub wykorzystanie krytycznego położenia, doprowadza inną osobę do obcowania płciowego, podlega karze (...) [art. $199 \S 1 \mathrm{KK}]$.

Próba ustalenia na podstawie omówionych powyżej kategorii, jakie formy kontaktów seksualnych należa do grupy obcowanie płciowe, jest możliwa wyłącznie na poziomie fragmentarycznym i okazjonalnym. Można zauważyć, że obcowanie płciowe w ramach kodeksu karnego zawsze występuje jako akt wykorzystania seksualnego, a postaci tego nadużycia sprowadzono do czynów kazirodczych, pedofilskich i powiazanych, skutków nieświadomości (podstęp, bezradność), aktów seksualnych pod przymusem bezpośrednim (groźba, przemoc) i pośrednim (presja).

Wymienione przykłady pozwalaja na wysnucie tylko cząstkowej interpretacji pojęcia <obcowanie płciowe>. Na podstawie tekstu ustawy możliwe stało się ustalenie, że obcowanie płciowe to rodzaj czynności seksualnej, por.:

- Kto, wykorzystując bezradność innej osoby (...) doprowadza ja do obcowania płciowego lub do poddania się innej czynności seksualnej, podlega karze (...) [art. $198 \mathrm{KK}$ ].

W taki sposób formułowane przepisy ustawy należało zinterpretować następująco: obcowanie płciowe to podstawowa forma realizowania czynności seksualnych (doprowadza ja do obcowania ptciowego), ale nie jedyna (lub do poddania sie innej czynności seksualnej).

Doprecyzowania pojęcia <obcowanie płciowe>, również niemającego definicji legalnej, podjęli się zarówno praktycy, jak i teoretycy prawa. $\mathrm{W}$ przeciwieństwie do konceptu <czynność seksualna> omawiane pojęcie, tj. <obcowanie płciowe>, zostało szeroko opisane w tekstach sadowych i doktrynalnych, por. m.in.:

- (..) obcowanie płciowe obejmuje swym przedmiotowym zakresem przede wszystkim akty spółkowania oraz (...) czynności seksualne stanowiące ich surogaty, traktowane przez sprawcę jako ekwiwalentne i równoważne spółkowaniu [WA 25/01];

- Pojęcie „obcowania ptciowego" obejmuje swym zakresem przede wszystkim klasyczne akty spółkowania heteroseksualnego (wprowadzenie członka do pochwy) jak i inne akty seksualne stanowiące surogaty spółkowania, traktowane (...) jako ekwiwalentne i równoważne spółkowaniu, a więc takie akty, które polegaja na bezpośrednim kontakcie płciowych części ciała jednego z uczestników aktu z płciowymi częściami drugiego uczestnika lub części płciowych jednego $z$ uczestników aktu z częściami ciała drugiego, które „biologicznie” płciowe 
co prawda nie sa, lecz sprawca traktuje je jako takie, wyładowując na nich lub za ich pośrednictwem swe libido (np. stosunek in ore lub per anum) [Filar 2002];

- [obcowanie płciowe to - J.K.] prawidlowy stosunek płciowy, który przede wszystkim polega na wprowadzeniu męskich narządów płciowych do żeńskich narządów płciowych oraz wszelkie inne odpowiedniki stosunków płciowych [Zoll (red.) 2008, 580];

- [obcowanie płciowe - J.K.] (...) nie oznacza (...) tylko normalnego i w pelni udanego stosunku płciowego (spółkowania). W szczególności jego elementem nie musi być immisio penis - np. conjunctio membrorum. Może to być też coitus in ore, coitus per anum lub stosunek przedsionkowy, a także wszelkie inne formy mogące być uznane za swego rodzaju ekwiwalent (...) stosunku płciowego $z$ pominięciem organów płciowych - np. inter femora lub in axilla, nawet jeżeli nie dochodzi do ejakulacji (emissio seminis). Pojęcie to obejmuje również stosunki homoseksualne (cunnilingus lub coitus cum viro) (...). Obcowanie płciowe należy potraktować jako termin szerszy, co do zakresu, od spółkowania [Warylewski 2004, 774].

Powyższe przykłady odzwierciedlają tendencje orzecznicze i doktrynalne. Co do zasady uznaje się, że obcowanie płciowe jest czynnością seksualną będąca spółkowaniem lub jego ekwiwalentem [por. m.in. Warylewski 2012; Kozielewicz 2012]. Trudności pojawiają się jednak w wypadku określenia, jakie są surogaty spółkowania, należące do katalogu form obcowania płciowego. Zachowawczość interpretacyjna jest widoczna już na poziomie stosowania wyrażeń przyimkowych, takich jak: przede wszystkim, w szczególności, a lista surogatów tworzona przez poszczególnych autorów (praktyków i naukowców) stanowi nieuporządkowaną próbę wskazania, które działania można uznać za podobne do spółkowania (penetracyjne vs niepenetracyjne, por.: [obcowanie płciowe to wyłacznie akt penetracyjny] „dotykanie narząów płciowych (...) nie mieści się w zakresie zachowań obejmowanych terminem obcowanie płciowe" [Wojciechowski 1997, 344; Wojciechowski 1998, 15 za: Warylewski 776]; [obcowanie płciowe to akty również niepenetracyjne] „Pojęcie to obejmuje również stosunki (...) cunnilingus" [Warylewski 2004, 774].

Kolejny problem to brak jednorodnej linii interpretacyjnej zwiazanej ze znaczeniem kontaktu fizycznego. W orzecznictwie i doktrynie funkcjonuja dwie równoległe tendencje: znamieniem obcowania płciowego jest kontakt organów płciowych lub ich cielesnych surogatów jednej osoby $z$ organami płciowymi lub ich cielesnymi surogatami innej osoby [por. m.in. II AKa 323/2006; Filar 2002; Rodzynkiewicz 2007, 600] albo kontakt organów płciowych lub ich cielesnych oraz niecielesnych surogatów (przedmiotów, narzędzi) jednej osoby $z$ organami płciowymi albo ich cielesnymi surogatami innej osoby [por. m.in. WA 25/01; II AKa 328/2006].

Biorąc pod uwage powyższe refleksje i dążąc do ujednolicenia istoty obcowania płciowego, można przyjąć, że obcowanie płciowe to kontakt organów płciowych jednej osoby albo ich cielesnych lub niecielesnych (przedmiotów, narzędzi) surogatów $z$ organami płciowymi lub ich cielesnymi surogatami innej osoby / istoty, majacy przynajmniej dla jednej ze 
stron charakter seksualny albo wywołujacy taki skutek (np. w formie naruszenia czyjejś wolności seksualnej; w formie znęcania się nad zwierzętami). W takiej perspektywie obcowanie płciowe nie jest - słusznie zdaniem autorki - wybiórczo determinowane forma aktywności płciowej (penetracyjna / niepenetracyjna), rodzajem surogatów narządów płciowych (cielesnych / niecielesnych), tradycyjnie ujmowanym aktem spółkowania czy powszechna para jego ekwiwalentów, tj. seksem analnym i oralnym (odnoszonym najczęściej do coitus in ore $\mathrm{z}$ pominięciem cunnilingus).

\section{POJĘCIE <INNA CZYNNOŚĆ SEKSUALNA>}

Ostatnim pojęciem, które zostanie omówione w ramach niniejszego artykułu, jest <inna czynność seksualna>. W odniesieniu do dwóch poprzednich konceptów stanowi najmniej sprecyzowaną formę kontaktów intymnych i co do zasady jej wyjaśnienia na poziomie jurysdykcyjnym oraz doktrynalnym opierają się na eksplikacjach apofatycznych lub pozytywnych i negatywnych egzemplifikacjach aktów seksualnych mogacych wchodzić w zakres pojęcia.

Wyjaśnienia negatywne wskazuja, że za inną czynność seksualną należy uznać każdą aktywność seksualną, niebędącą obcowaniem płciowym, por.:

- Inna czynność seksualna (...) to takie zachowanie nie mieszczące się w pojęciu „obcowanie płciowe", które zwiazane jest z szeroko rozumianym życiem płciowym człowieka, polegające na kontakcie cielesnym sprawcy z pokrzywdzonym lub przynajmniej na cielesnym i mającym charakter seksualny zaangażowaniu ofiary [I KZP 17/99];

lub nie jest penetracyjną formą aktów seksualnych, a nawet nie wymaga bezpośredniego kontaktu fizycznego, por.:

- [inna czynność seksualna polega - J.K.] obejmuje wszystkie sytuacje doprowadzenia do znoszenia przez ofiarę zachowania sprawcy, polegającego na wejściu $\mathrm{w}$ kontakt seksualny $z$ intymnymi sferami ciała ofiary, który to kontakt nie jest jednak polączony $\mathbf{z}$ ich penetracja. (...) Do przyjęcia, że mamy do czynienia $z$ wykonaniem innej czynności seksualnej, nie jest konieczne, by doszło do bezpośredniego kontaktu fizycznego między ciałem sprawcy i ofiary [Bielski 2008, 227-228].

Interpretacje egzemplifikacyjne pozytywne zwracaja uwagę na pewne typy zachowania, które można / należy kwalifikować jako inną czynność seksualna, por.:

- Z pewnościa taka czynnościa jest dotykanie narządów płciowych lub odbytu (...), wprowadzanie tam różnych przedmiotów (...) [Marek 2004, 452];

- Inna czynnościa seksualna (...) sa w szczególności stosunki oralne w formie cunnilingus, stosunek dopachowy (coitus in aksila), stosunek międzyudowy 
(coitus femoralis), cinepimastria, onanizowanie(...), niepenetracyjny kontakt z narządami płciowymi lub odbytem ofiary, dotykanie piersi ofiary oraz wykonywanie wszelkich podobnych manipulacji w obrębie sfer intymnych np. przez dotykanie ich przedmiotami martwymi [Bielski 2008, 228].

Z kolei egzemplifikacje negatywne stanowiły wyliczenia takich typów zachowania, których nie można / nie należy zaliczać do katalogu przejawów wykonywania innej czynności seksualnej, por.:

- (...) wykracza poza zakres racjonalnej wykładni (...) dotykanie piersi kobiety [Marek 2004, 452];

- Nie spełniaja natomiast przyjętego kryterium (...) takie zachowania, jak np. wymuszenie pocałunku, uszczypnięcie w pośladek, złapanie za kolano czy wszelkie formy werbalnej lub gestykularnej molestacji [Bielski 2008, 229].

Analiza interpretacji i wyjaśnień terminu inna czynność seksualna ujawniła wyjątkową niespójność co do semantyki pojęcia. Jedynym punktem wspólnym okazało się stanowisko związane $z$ brakiem konieczności kontaktu fizycznego między stronami bioraccymi udział w akcie seksualnym. Pozostałe kryteria miały charakter uznaniowy i zbudowały sprzeczne linie interpretacyjne. Nie ma bowiem jednomyślności w odniesieniu do esencjonalnych cech innej czynności seksualnej.

Antagonizm poznawczy dotyczył praktycznie każdego pola semantycznego. $Z$ jednej strony funkcjonują poglądy głoszące, że inna czynność seksualna to wyłącznie akt niepenetracyjny [Bielski 2008, 227], z drugiej zaś, że może być aktem penetracyjnym, np. włożenie palca do pochwy [por.: Stefański 2004, 389]. Według niektórych uzasadnień dotykanie pewnych miejsc intymnych, np. dotykanie piersi, jest inna czynnościa seksualna [por. VKK 139/08], a według innych - nie [Marek 2004, 452]. Niektórzy autorzy uzależniają seksualny wymiar działania od tego, czy osoba dotykana miała na sobie odzież [por. Warylewski 1999], a część badaczy / praktyków nie odnosi tego kryterium do grupy determinantów [por. m.in. red. Ostrowski, Królikowski 2012, 301; Wrześniewski 2012, 44]. Rozbieżności pojawiaja się również w kontekście oceny tzw. czynów lubieżnych, a przede wszystkim aktów ekshibicjonistycznych, wymuszonych pocałunków, nieprzyzwoitych gestów i słów, które bywały oceniane jako forma innej czynności seksualnej [por. Leszczyński 1992, 81] lub uznawane jedynie za naruszenie obyczajności społecznej [por.: Wrześniewski 2012, 46; Kurzępa 2005, 65; Bielski 2008, 229].

$\mathrm{W}$ świetle powyższych ustaleń należy zauważyć, że w opracowaniach doktrynalnych i orzeczeniach sądowych ustalenia semantyczne skupiaja się na jednej gałęzi prawnej, zasygnalizowanej przez ustawodawcę w Kodeksie karnym, tj. na wolności seksualnej. Pomijany jest aspekt obyczajności, który występuje w tym akcie normatywnym równolegle (np. przestępstwa przeciw wolności seksualnej i obyczajności). Inne czynności seksualne są bliższe właśnie pojęciu <obyczajności>, a więc 
najmniej inwazyjnej formie zaspokajania potrzeb seksualnych lub godzenia w seksualność. Opierając się na tych założeniach, należy przyjąc, że inna czynność seksualna to każda forma czynności seksualnej niebędaca obcowaniem płciowym, tj. jednostronnie płciowe (np. masturbowanie się) lub pozapłciowe / quasi-płciowe - jednostronne lub dwu- i więcej - (np. tzw. ocieractwo) zachowanie o charakterze erotycznym. $Z$ punktu widzenia prawa karnego warto doprecyzować, że stanowi ona szczególny rodzaj czynności seksualnej o mniejszej szkodliwości społecznej lub osobistej niż obcowanie płciowe, ale jednocześnie nie jest definiowana przez inne ustawy np. jako wykroczenie, a nie przestępstwo.

\section{ZAKOŃCZENIE}

Pragmatyka rozpatrzonej w niniejszym artykule domeny seksualność ukazała niejednorodna semantykę pojęć, budujących polskojęzyczny dyskurs prawny. W świetle konceptów uogólnionych, takich jak prawa seksualne oraz wolność seksualna i obyczajność, podjęto próbę uspójnienia znaczeń fundamentalnych terminów prawnych, nazywajacych różne formy aktywności seksualnej: czynność seksualna, obcowanie płciowe oraz inna czynność seksualna.

W pierwszej fazie oglądu wykazano, że w komunikacji prawnej badane pojęcia maja bilateralną naturę, gdyż z jednej strony ustawodawca nadał im status dóbr chronionych prawem (wolność seksualna), a $z$ drugiej - działań będacych przestępstwem (godzenie w wolność seksualna innych osób). Definiowanie poszczególnych jednostek uwzględniało tę dwubiegunowość.

$\mathrm{Na}$ podstawie przeprowadzonej analizy ustalono, że pojęcia: <czynność seksualna>, <obcowanie płciowe> i <inna czynność seksualna> sa stopniami natężenia korzystania $z$ wolności seksualnej lub godzenia $\mathrm{w}$ nią. <Czynność seksualna> to pojęcie ogólne, w którego zakres wchodzi zarówno <obcowanie płciowe>, jak i <inne czynności seksualne>. Obcowanie płciowe nawiąuje do fizycznego i jednocześnie bezpośredniego korzystania $z$ wolności seksualnej lub naruszania jej. $Z$ kolei inna czynność seksualna jest bliższa pojęciu obyczajności, a więc stanowi najmniej inwazyjny, a jednocześnie najmniej konwencjonalny sposób zaspokajania potrzeb seksualnych lub naruszania wolności seksualnej.

\section{Materiały źródłowe}

I C 377/14 - Wyrok Sadu Okręgowego w Stupsku z dn. 30 czerwca 2017 roku, syg. akt I C $377 / 14$.

I KZP 17/99 - Uchwała Sądu Najwyższego z dn. 19 maja 1999 r., syg. akt I KZP $17 / 99$. 
II AKa 142/ 11 - Wyrok Sadu Apelacyjnego w Katowicach z dn. 2 czerwca 2011, syg. akt II AKa 142/11.

II AKa 294/ 16 - Wyrok Sądu Apelacyjnego w Gdańsku z dn. 9 lutego 2017 roku, syg. akt II AKa 294/16.

II AKa 323/2006 - Wyrok Sadu Apelacyjnego w Katowicach z dn. 9 listopada 2006 roku, syg. akt II AKa 323/2006.

II AKa 328/2006 - Wyrok Sadu Apelacyjnego w Katowicach z dn. 15 listopada 2006 roku, syg. akt II AKa 328/2006.

II KKN 349/98 - Postanowienie Sądu Najwyższego z dn. 2 kwietnia 2001 roku, syg. akt II KKN 349/98.

IV Ka 360/14 - Wyrok Sąu Okręgowego w Piotrkowie Trybunalskim z dn. 1 lipca 2014 roku, syg. akt IV Ka 360/14.

DPS - Deklaracji praw seksualnych, Światowa Organizacja Zdrowia, sierpień 2002.

DPSC - Deklaracji praw seksualnych człowieka, Światowa Organizacja Zdrowia Seksualnego, marzec 2014.

KK - Kodeks karny z dn. 6 czerwca 1997 roku, Dz. U. 1997, nr 88, poz. 553.

KW - Kodeks wykroczeń z dn. 20 maja 1971 roku, Dz. U. 1971, nr 12, poz. 114.

UoOZ - Ustawa o ochronie zwierzat z dn. 21 sierpnia 1997 roku, Dz. U. 1997, nr 111, poz. 724.

VKK 139/08 - Postanowienie Sąu Najwyższego z dn. 21 maja 2008 roku, syg. akt VKK 139/08.

WA 25/01 - Wyrok Sadu Najwyższego z dn. 26 października 2001 r., syg. akt WA 25/01.

\section{Bibliografia}

M. Budyn-Kulik, 2008, Inna czynność seksualna. Analiza dogmatyczna i praktyka ścigania, „Prawo w Działaniu” nr 5, s. 132-194.

M. Filar, 2002, Glosa do Wyroku Sądu Najwyższego z dn. 26 października 2001 r., syg. akt WA 25/01, „Orzecznictwo Sądów Polskich” nr 6.

N. Glińska, 2016, Własne ciało - operatywność praw seksualnych i reprodukcyjnych $w$ Polsce, „Folia Iuridica Universitatis Wratislaviensis” nr 5 (2), s. $35-52$.

A. Grześkowiak (red.), 2012, Prawo karne, Warszawa.

W. Kozielewicz, 2012, Pojeccia „czyn nierzadny”, „czyn lubieżny”, „obcowanie płciowe” $i$,inna czynność seksualna” $w$ orzecznictwie Sąu Najwyższego [w:] M. Mozgawa (red.), Przestepstwo zgwałcenia, Warszawa.STRONY

B. Kurzępa, 2005, Inna czynność seksualna jako znamię przestępstw, „Prokuratura i Prawo" nr 5, s. 62-72.

J. Leszczyński, 1992, O projektach reformy przepisów dotyczacych przestępstw seksualnych, „Państwo i Prawo” nr 2, s. 80-84.

A. Marek, 2002, Kodeks karny. Komentarz, Warszawa.

M. Ostrowski, M. Królikowski (red.), 2012, Prawo karne. Część szczególna. Orzecznictwo, Warszawa.

R. Paprzycki, 2008, Czy bluźnierca jest przestepca?? Rozważania na temat znamienia „przedmiotu czci religijnej” przestepstwa obrazy uczuć religijnych art. 196 k.k., „Palestra” nr 5-6, s. 81-90. 
M. Rodzynkiewicz, 2007 [w:] A. Zoll (red.), Kodeks karny. Część ogólna. Komentarz, t. 1: Komentarz do art. 1-116 k.k., Warszawa.

R.A. Stefański, 2004, Kodeks karny z orzecznictwem i piśmiennictwem (za lata 1998-2003), Toruń.

J. Warylewski, 2004, [w:] A. Wąsek (red.), Kodeks karny. Część szczególna. Komentarz, t. 1, Warszawa.STRONY

J. Warylewski, 1999, Glosa aprobujaca $z$ pewnymi zastrzeżeniami do wyroku Sądu Najwyższego z dn. 19 maja 1999 r., „Orzecznictwo Sądów Polskich” nr 12, poz. 224.

J. Warylewski (red.), 2012, System prawa karnego. Przestepstwa przeciwko dobrom indywidualnym, t. X, Warszawa.

J. Wojciechowski, 1997, Kodeks karny. Komentarz, Warszawa.

J. Wojciechowski, 1998, Przestepstwo zgwałcenia, „Rzeczpospolita” nr 20/3.

W. Wróbel, M. Bielski (red.), 2011, Materiały do nauki części szczególnej prawa karnego materialnego. Kazusy, Warszawa.

M. Wrześniewski, 2012, Czynność seksualna a obcowanie płciowe $i$ inna czynność seksualna - próba uporządkowania pojęć, „Acta Iuris Stetinensis” nr 3, z. 720, s. 37-49.

Z. Zoll (red.), 2008, Kodeks karny. Część szczególna. Komentarz, t. II, Kraków.

\section{On the non-standardised semantics of the terms czynność seksualna (sexual act), inna czynność seksualna (another sexual act), and obcowanie plciowe (sexual intercourse) in legal discourse}

\section{Summary}

This paper discusses three basic legal terms describing forms of sexual activity, i.e. czynność seksualna (sexual act), obcowanie płciowe (sexual intercourse), and inna czynność seksualna (another sexual act). The overview was made against generalised concepts of prawa seksualne (sexual rights) and wolność seksualna i obyczajność (sexual freedom and decency). Consideration was given to pragmatic bipolarity of all terms, which assumed the form of torts or interests protected by law in legal texts and texts of the law.

It was also noticed that there was no consistency in the methods of determining the meanings of the examined units in terms of jurisdiction and views of legal academics and therefore the study made an attempt at defining the indicated terms by capturing and interpreting ontological characteristics, which separate each concept semantically.

The methodological structure was the linguistic and systemic criterion, which enabled the analysis of the identified terms in accordance with the special pragmatics of legal discourse.

Keywords: sexual act - another sexual act - sexual intercourse - semantics discourse 